\title{
The Impact of Internal Corporate Governance Mechanisms on the Unsystematic Risks at Jordanian Commercial Banks Listed on the Amman Stock Exchange
}

\author{
Eljaser Alelfartas \\ Faculty of Economics and Social Sciences, Department of Business Administration, \\ Kastamonu University. Turkey
}

\begin{abstract}
The aim of this research is to investigate the relationship between Internal corporate governance mechanisms and on the unsystematic risks using data from 13 commercial banks listed on the Amman Stock Exchange during the period 2009-2016. Panel data was utilized and the data gathered from 104 annual reports from 13 commercial banks in Amman, which analyzed using descriptive statistics, correlation, and regression. Seven main corporate governance variables were analyzed in terms namely: (Board size, Board Independence, CEO /Chairman Separation, Audit Committee Independence, Ownership concentration, Institutional Ownership, and Foreign Ownership) their relative of the unsystematic risk (credit risk, liquidity risk, and operational risk). furthermore, bank size and debt Ratio were used as a control variable. Based on the results of the study, it has been observed that Internal corporate governance mechanisms variables have a significant effect on the unsystematic risk.
\end{abstract}

Keywords: Corporate Governance, Unsystematic Risk, Panel Data.

DOI: $10.7176 /$ RJFA/10-18-01

Publication date:September $30^{\text {th }} 2019$

\section{INTRODUCTION}

Last decade, some successful banks collapsed suddenly after a good performance. For example, in the UK, Northern Rock was one of the FATS 100s, but in February 2008 it was nationalized by the government. In the US, this problem has increasingly sparked the fare of investors affecting the bank industry in particular and market indices, not only in the UK but also in the world(Sants, 2008) states that "the FSA acknowledges that its supervision of Northern Rock in the period leading up to July 2007 was not of sufficient intensity or appropriate rigour to challenge the company's board and executive on their risk management practices and their understanding of the risks posed by their business model".

Corporate Governance has received considerable attention, especially following the massive costly corporate scandals that have focused on the possibility that many problems with the reason to structural factors. In particular, collapses such as those that occurred at Maxwell Communications Corporation (MCC), Enron, Parmalat and others, suggested that the failure, or inability, of boards of directors to control and monitor business, laxity in accounting standards and an ethos of contented indifference on the part of many business leaders, had played important roles. In response, many committees have been formed (e.g., Cadbury Report 1992, Smith report 2003, Higgs Report 2003) conclude many recommendations to reform the corporate governance status. Among the significant recommendations are the board of directors responsible for the risk that faces the company in the business environment for international environments(Aksoy \& Dayi, 2017).

The Financial Times (2008) reported that one of the main reasons for the world's largest investment bank, such as Goldman Sachs, Morgan Stanley and Citigroup, was risk management deficiencies. The author of the report Hal Weitzman calls for a review of risk management strategies and system procedures. Skypala (2008) of the Financial Times is blaming executives for not using risk management when using funds.( $T$ Ulusoy, 2008a)states that government bonds also useful for anti-collapse role of business. Another reason for the collapse of Enron is the conflict between managers and shareholders, which causes the manager acted for their own interests and although that was against the targets of shareholders. Maybe, they can fail financial failure(Civan \& Day1, 2014).

According to the Basel Committee on Bank Supervision, effective corporate governance practices are essential to achieving and maintaining public trust and confidence in the banking system, which is critical for proper functioning of the banking sector and the economy as a whole((BIS), 2014). Because the banking system plays a very important role in the economy, corporate governance is important and risk management is essential in financial institutions(Trinh, Duyen, \& Thao, 2015).

Therefore, researches on corporate governance and risk management have been interested in the recent academic literature(McNulty, Florackis, \& Ormrod, 2012; Salhi \& Boujelbene, 2012; Tsorhe, Aboagye, \& Kyereboah-Coleman, 2011; Zhong, Gribbin, \& Zheng, 2007) emphasized the impact of board strengths and stakeholder behaviours on the management of bank capital risk, credit risk, and liquidity risk. Some other researches about systematic risk(T Ulusoy, 2008b). 
Jordan is a small country with limited resources; its financial market is aiming to the principles of equality, transparency and effectiveness. However, Jordan like other countries also experienced financial collapses such as Shamaylaeh Gate, which forces regulatory bodies to adopt a sequence of legislative, economic and financial reforms that intended to promote transparency, accountability and the rule of law in the economic life of the country(JFED, 2003). In 2005, the Jordan Securities Commission (JSC)'s announced the first Jordanian corporate governance codes for corporations listed in the ASE for the purpose of establishing a solid framework that regulates their relations and defines their responsibilities to safeguard shareholders.

The aspects of corporate governance in banking business, such as the characteristics of the board of directors, salaries and executive heads, have been addressed in a few recent academic studies (eg, Beltratti and Stulz, forthcoming; Erkens et al., 2010; Fahlenbrach and Stulz, 2011). However, corporate governance literature and the impact of corporate governance in financial firms are still very limited especially the case of a developing country such as that of Jordanian. Financ0ial institutions have their own characteristics, such as high transparency, tight regulation, and intervention by a government. During establishing characterization of firms; governments also point out the financial power of own country(Tolga Ulusoy, 2011).

This work investigates on the assessment of the link existing between Internal corporate governance mechanisms on the unsystematic risks. Moreover, we have used in this model to comprises two control variables related to variables characteristics; namely the bank size, and debt Ratio that it shows the effect of independent variables with dependent variables, as well as reduce random errors in the model through previous studies. Also, we suggest that the findings of this study could prove significant to regulators, investors, academics and others who argued that good corporate governance is important for raising investor assurance and market liquidity (Donaldson, 2003). With the compliance focusing on corporate governance presented by the Jordanian authorities, such as the report of finance committee on corporate governance, the Jordanian code of corporate governance and Jordanian stock exchange listing requirements. So, this paper will approach the impact of Internal corporate governance mechanisms on the unsystematic risks at Jordanian commercial banks listed on the Amman stock exchange.

The paper proceeds as follows. In Section 2: Hypotheses and conceptual framework. Section 3: we show empirical analysis. The final section provides a summary and conclusion.

\section{HYPOTHESES AND CONCEPTUAL FRAMEWORK}

\subsection{Cconceptual Framework}

Figure (1) is shown to suggested for study mode conceptual frameworks are formed as below: Independent variable

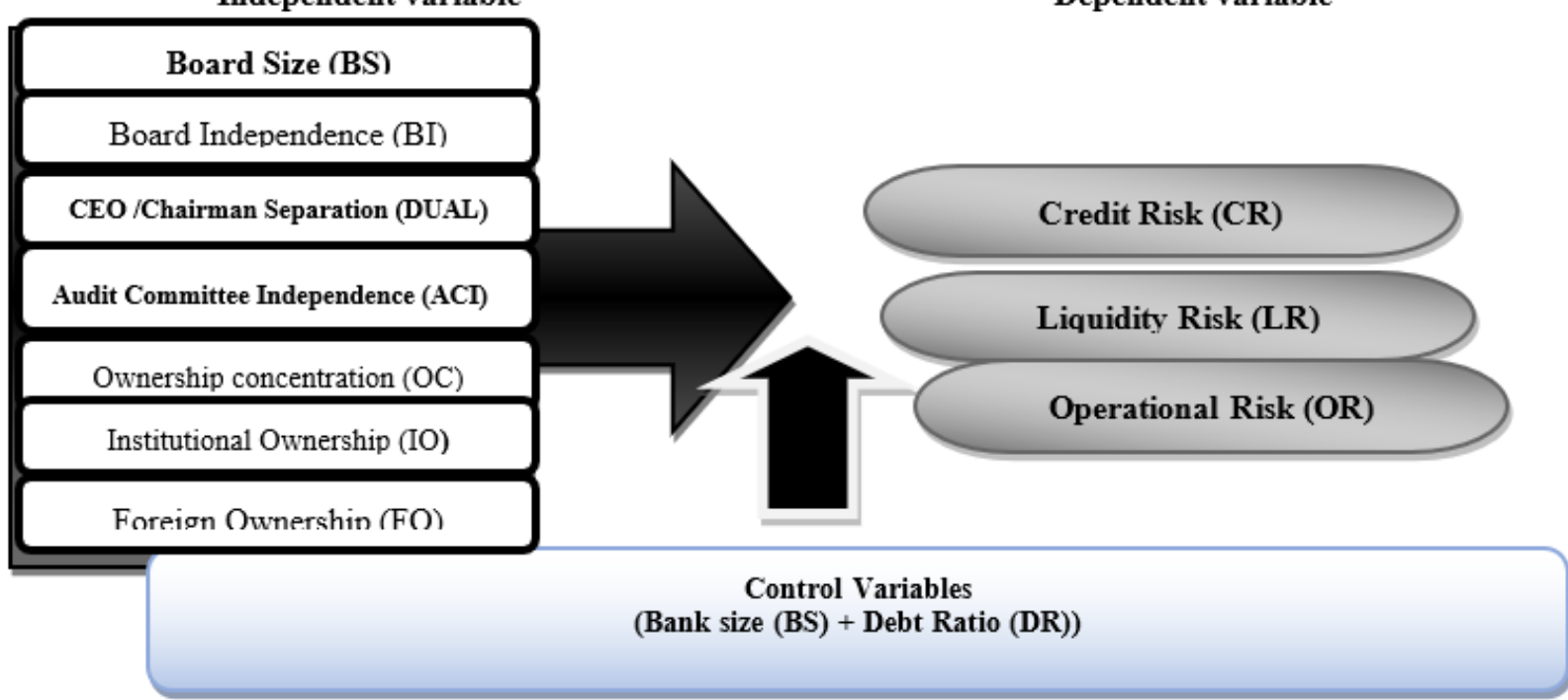

The researcher relied on the answer to the problem and objectives of the paper with the following main hypothesis:

H1: There is an effect with a clear statistic significant between the impact of Internal corporate governance mechanisms and the unsystematic risk in Jordanian Commercial Banks listed on the Amman Stock Exchange.

The main hypothesis divided three hypotheses

H1. There is an effect with a clear statistic significant between the impact of Internal Corporate Governance Mechanisms and Credit Risk.

H2. There is an effect with a clear statistic significant between the impact of Internal Corporate Governance Mechanisms and liquidity risk .

H3. There is an effect with a clear statistic significant between the impact of Internal Corporate Governance 
Mechanisms and operational risk.

\subsection{Study variables}

This section will be displayed the Seven independent variables include (Board size, Board Independence, CEO /Chairman Separation, Audit Committee Independence, Ownership concentration, Institutional Ownership, and Foreign Ownership) and the dependent variables (credit risk, liquidity risk, and operational risk). In addition, two control variables; namely the bank size and debt Ratio. The empirical model is as follow:

\subsubsection{Internal Corporate Governance Mechanisms Variables}

\subsubsection{The Board Size (BS)}

The board of directors consider an important part of the governance structure of companies, The board of directors considers an important part of the governance structure of companies where, that the small size of the board to be more balanced and leads to increases their efficiency, coordination, and accuracy in decision-making and improve company performance(Alhumoudi, 2016; Christensen, Kent, \& Stewart, 2010; Marn \& Romuald, 2012).

\subsubsection{The Board Independence (BI)}

Institutional investors play an active role in the governance of banks. Indeed, Jensen noted that the presence of institutional directors on the boards of directors allows better control of the executive, as these Directors have better access to information and greater expertise in the management of bank risks(Jensen, 1993).

\subsubsection{CEO /Chairman Separation (DUAL)}

The literature on duality or plurality of positions of the CEO and chairman of the board of directors has separate opinions. Some authors argue for accumulated reasons of efficiency management unit (Fogelberg \& Griffith, 2000)and others denounced for abuse of power by the executive(Fama \& Jensen, 1983; Pathan, 2009; Pi \& Timme, 1993). When the CEO is the same person who holds the position of the Board Chairman, the capacity to influence decisions within the board will increase.

\subsubsection{Audit Committee Independence (ACI)}

The role of the board involves the formulation and supervision of strategic objectives. For efficiency reasons, certain tasks are assigned to smaller groups; that is, committees, based on the members' expertise and interests(Christensen et al., 2010).

\subsubsection{Ownership concentration (OC)}

In terms of block ownership, it has been argued that the greater the number of benefits (usually measured in 5\%), will show concern for business performance, which is more important than that of shareholders(Marn \& Romuald, 2012).

\subsubsection{Institutional Ownership (IO)}

Institutional shareholders, who have a large number of shares, play a very important role in overseeing the company and their ability to supervise managers(Marn \& Romuald, 2012).

\subsubsection{Foreign Ownership (FO)}

The privatization and the entry of foreign banks and private banks newly existing increased their risk of the asset portfolio where the presence of foreigners in the ownership structure is negatively related to bank efficiency(Lensink \& Morrissey, 2006; Shrieves \& Dahl, 1992).

\subsubsection{The Unsystematic Risks Variables}

\subsubsection{Credit Risk (CR)}

Credit risk considered as one of the main risks because it is connected with all activities where Its objective to maintain the efficiency of the business activities and the continuity of the business (Spuchláková, Valašková, \& Adamko, 2015).

\subsubsection{Liquidity Risk (LR)}

Liquidity risk refers to the probability relating institutions ability to provide enough funds to meet their obligations when they. SO, the banks' risk-taking behavior and bank performance have impacted by the regulatory environment(Ly, 2015; Woods \& Dowd, 2008).

\subsubsection{Operational Risk (OR)}

The committee adopted a unified industry definition for operational risks, namely: "The risk of direct or indirect loss resulting from the insufficiency or failure of internal processes, personnel, systems, or external events (SUPERVISION, 2010).

\subsubsection{The control variables}

It was added in order to control the relationship between independent variables and dependent variables, view the effect of independent variables with dependent variables, as well as reduce random errors in the model through previous studies (Liao, Mukherjee, \& Wang, 2015; Obradovich \& Gill, 2013; Tahir, Rehman, \& Rehman.Naveed, 2015; Yaseen \& Al-Amarneh, 2015), and the most important of these variables bank size and debt ratio.

\subsection{RESEARCH METHODOLOGY}

This study is considered of the applied studies, which is based on private data of Jordanian banks, the study adopted 
the descriptive analytical approach in attempting to make meaningful inferences relating to the relationship of corporate governance variables and the unsystematic risk of the chosen sample.

\subsubsection{Society and the research sample}

The study population consisted of all Jordanian commercial banks listed on the Amman Stock Exchange, and their number (13) banks, the study relied of series of the annual of corporate governance reports and financial statements of the commercial banks during the period (2009 -2016), where they were collected 104 annual reports from 13 commercial banks in Amman.

\subsubsection{Data analysis}

The data for the study variables will be collected from the annual reports of the study banks for the period of study 2009-2016 and Statistical analysis will be employed in this study in order to examine the relationship among variable, to test the hypotheses and validate the findings. The data collected will be analysed using the E-views 6 to perform the correlation test, the regression test, and the descriptive statistical analysis.

Model Specification

\subsubsection{The Measure of the unsystematic risk}

This section aims to present the empirical model of the study. The dependent variable is the unsystematic risk (credit risk, liquidity risk, and operational risk). The Seven independent variables include: -: Board size, Board Independence, CEO /Chairman Separation, Audit Committee Independence, Ownership concentration, Institutional Ownership, and Foreign Ownership. Finally, this model also comprises two control variables related to variables characteristics; namely the bank size and debt Ratio. The empirical model is as follow:

The first model

$\mathrm{CREDR}=\beta 0+\beta 1(\mathrm{BS})+\beta 2(\mathrm{BI})+\beta 3(\mathrm{DUAL})+\beta 4(\mathrm{ACI})+\beta 5(\mathrm{OC})+\beta 6(\mathrm{IO})+\beta 7(\mathrm{FO})+\beta 8(\mathrm{SIZE})+\beta 9+(\mathrm{DR})+\varepsilon \mathrm{t}$ The second model

$\mathrm{LIQR}=\beta 0+\beta 1(\mathrm{BS})+\beta 2(\mathrm{BI})+\beta 3(\mathrm{DUAL})+\beta 4(\mathrm{ACI})+\beta 5(\mathrm{OC})+\beta 6(\mathrm{IO})+\beta 7(\mathrm{FO})+\beta 8(\mathrm{SIZE})+\beta 9+(\mathrm{DR})+\varepsilon \mathrm{t}$ The third model

$\mathrm{OPR}=\beta 0+\beta 1(\mathrm{BS})+\beta 2(\mathrm{BI})+\beta 3(\mathrm{DUAL})+\beta 4(\mathrm{ACI})+\beta 5(\mathrm{OC})+\beta 6(\mathrm{IO})+\beta 7(\mathrm{FO})+\beta 8(\mathrm{SIZE})+\beta 9+(\mathrm{DR})+\varepsilon$

Table 1: Measure study variables

\begin{tabular}{|c|c|c|}
\hline \multicolumn{3}{|c|}{ Dependent Variable: Risk Management } \\
\hline Variable & Indicator(s) & Measurement(s) \\
\hline \multirow{6}{*}{ Banking Risks } & Credit Risk & $\begin{array}{l}\text { Non-Performing Loans Ratio (NPLR) to Total } \\
\text { gross loan }\end{array}$ \\
\hline & Liquidity Risk & Liquidly Ratio (LR) \\
\hline & & Cash Assets to Total Assets \\
\hline & Capital Adequacy & Capital Adequacy Ratio (CAR) \\
\hline & Operation Risk & Basic Indicator Approach: \\
\hline & & Capital required to meet operational risks \\
\hline \multicolumn{3}{|c|}{ Independent Variable: Corporate Governance Mechanisms } \\
\hline \multirow{7}{*}{$\begin{array}{l}\text { Corporate } \\
\text { Governance } \\
\text { Mechanisms }\end{array}$} & Board Size (BS) & The number of members on a board in a year \\
\hline & Board Independence (BI) & $\begin{array}{l}\text { The ratio of non-executive directors to total } \\
\text { board directors }\end{array}$ \\
\hline & CEO /Chairman Separation & $\begin{array}{l}\text { Dummy variable } 1 \text { if there's a Separation; } 0 \text { if } \\
\text { not }\end{array}$ \\
\hline & $\begin{array}{l}\text { Independence of the Audit } \\
\text { Committee (IAC) }\end{array}$ & $\begin{array}{l}\text { The proportion of an independent non-executive } \\
\text { of number Committee to the total number of } \\
\text { Audit Committee Audit Committee size }\end{array}$ \\
\hline & $\begin{array}{l}\text { Ownership concentration (OC) } \\
\text { (Large Shareholders) }\end{array}$ & $\begin{array}{l}\text { Ratio of Shareholders Ownership have } 5 \% \text { or } \\
\text { more from bank shares }\end{array}$ \\
\hline & Companies Ownership (CO) & $\begin{array}{l}\text { The proportion of bank shares owned by } \\
\text { companies }\end{array}$ \\
\hline & Foreign Ownership (FO) & $\begin{array}{l}\text { The proportion of ownership of foreign } \\
\text { investors who own shares in the bank }\end{array}$ \\
\hline \multicolumn{3}{|l|}{ Control Variable } \\
\hline Bank size (BS) & $\begin{array}{l}\text { Size of the Bank measured by total } \\
\text { assets. }\end{array}$ & Log of total assets. \\
\hline Debt ratio & $\begin{array}{l}\text { Represents the relationship } \\
\text { between a bank's long-term debt } \\
\text { and its book value of equity. }\end{array}$ & Ratio of long-term debt to book value of equity \\
\hline
\end{tabular}




\section{EMPIRICAL ANALYSIS}

\subsection{Descriptive statistical analysis}

The summary of the descriptive statistics for the panel data in all Jordanian commercial banks listed on the Amman Stock Exchange is reported in Table 2. It shows the distribution of the unsystematic risk measurement (credit risk, liquidity risk, and operational risk) and Internal corporate governance mechanisms variables (Board size, Board Independence, CEO /Chairman Separation, Audit Committee Independence, Ownership concentration, Institutional Ownership, and Foreign Ownership). furthermore, control variables (bank size and debt Ratio).

Table 2: Descriptive statistics

\begin{tabular}{|l|l|l|l|l|}
\hline Variables & Mean & Max & Min & Stdev \\
\hline CR & 9.16 & 22.40 & 1.84 & 4.11 \\
\hline LR & 12.07 & 27.79 & 4.07 & 4.91 \\
\hline OR & 17.38 & 19.86 & 15.57 & 1.01 \\
\hline BS & 10.7 & 14.0 & 6.0 & 1.8 \\
\hline BI & 37.2 & 77.8 & 0.0 & 15.8 \\
\hline DUAL & 10 & 9.62 & 94 & 90.4 \\
\hline ACI & 59.5 & 75.0 & 20.0 & 15.5 \\
\hline OC & 59.7 & 88.5 & 21.3 & 20.1 \\
\hline IO & 8.37 & 91.86 & 0.00 & 13.26 \\
\hline FO & 35.2 & 89.1 & 0.0 & 29.7 \\
\hline SIZE & 21.4 & 24.0 & 19.5 & 1.0 \\
\hline DR & 85.7 & 93.5 & 78.0 & 2.6 \\
\hline
\end{tabular}

The table above shows the descriptive statistics of the variables used in the study. The mean of credit risks for all banks for the period 2009 - 2016, was $(9.16 \%)$, with standard deviation $(4.11 \%)$. While, The mean value $(12.07 \%)$ liquidity risks, with standard deviation (4.91\%) for all banks for the period 2009-2016. Also, the mean of operating risks for all banks for the period 2009 - 2016, was (17.38\%), with standard deviation (1.01\%).

The board size was (10.7), with standard deviation (1.8) for all banks for the period 2009 - 2016. Regarding board independence, the sample means the value of (37.2\%) shows that the ratio of independent non-executive directors (INEDAC) is slightly close to the half of the total number of the directors, with standard deviation (15.8\%) for all banks for the period 2009 - 2016, With regards to shows that the duality for all banks for the period 2009 2016, where the number of observations of duality was (10), which formed (9.62\%) of all observation, while the number of observations of no duality was (94), which formed (90.4\%) of all observation. We can note that, almost, all bank appeared no duality, except for (Bank of Jordan) appeared duality throughout the whole period. Also, the means of audit committee independence for all banks for the period $2009-2016$, was (59.5\%), with standard deviation (15.5\%) shows that the audit committee is mostly composed by independent non-executive directors. For Ownership Concentration, the mean values were (59.7\%), with standard deviation (20.1\%). The mean of institutional ownership for all banks for the period 2009 - 2016, was (8.37\%), with standard deviation (13.26\%). With regards to the mean of foreign ownership for all banks for the period 2009-2016, was (35.2\%), with standard deviation $(29.7 \%)$.

furthermore, the bank size shows that the mean value (natural logarithm of total assets) for all banks for the period 2009 - 2016, was (21.4), with standard deviation (1.0). While, shows that the mean of debt ratio for all banks for the period $2009-2016$, was $(85.7 \%)$, with standard deviation $(2.6 \%)$.

\subsection{Correlation analysis}

\subsubsection{Testing for unit root}

While working with time series data we need to test them for stationary. This test is processed to determine if there is a systematic change in either the mean or the variance in the data, if not it should be treated appropriately, to misleading estimates and spurious regression. The verification of unit root is done in practice by using unit root tests such as Dickey-Fuller, Augmented Dickey-Fuller(Dickey \& Fuller, 1979) and Phillips-Perron tests (Phillips \& Perron, 1988). Augmented Dickey-Fuller test is employed which requires the estimation of the following equation

$$
\Delta \mathrm{Y}_{\mathrm{t}}=\alpha+\beta \mathrm{Y}_{\mathrm{t}-1}+\sum_{\mathrm{i}=1}^{\mathrm{n}} \gamma_{\mathrm{i}} \Delta \mathrm{Y}+\varepsilon_{\mathrm{t}}
$$

The lag order $n$ is chosen to satisfy the criteria of no autocorrelation. The null hypothesis of presence of nonstationary behaviour is essentially the test of weather $\beta=0$ or no. 
Table 3: Unit Root test

\begin{tabular}{|c|c|c|c|c|}
\hline Variables & ADF & Prob. & $\mathbf{P P}$ & Prob. \\
\hline CR & $\begin{array}{l}-5.710185^{*} \\
(-3.495677) \\
\end{array}$ & 0.0000 & $\begin{array}{l}-3.089204 * * \\
(-2.889753) \\
\end{array}$ & 0.0305 \\
\hline LIQ & $\begin{array}{l}-6.184902 * \\
(-3.495021) \\
\end{array}$ & 0.0000 & $\begin{array}{l}-6.100982 * \\
(-3.495021) \\
\end{array}$ & 0.0000 \\
\hline OPR & $\begin{array}{l}-2.688762 * * * \\
(-2.581890)\end{array}$ & 0.0794 & $\begin{array}{l}-2.647095^{* * *} \\
(-2.581890)\end{array}$ & 0.0870 \\
\hline BS & $\begin{array}{l}-4.517483^{*} \\
(-3.495021)\end{array}$ & 0.0003 & $\begin{array}{l}-4.686141^{*} \\
(-3.495021)\end{array}$ & 0.0002 \\
\hline BI & $\begin{array}{l}-5.220080 * \\
(-3.495021)\end{array}$ & 0.0000 & $\begin{array}{l}-5.251809 * \\
(-3.495021)\end{array}$ & 0.0000 \\
\hline DUAL & $\begin{array}{l}-1.390667 \\
(-2.582041)\end{array}$ & 0.5841 & $\begin{array}{l}-4.284275^{*} \\
(-3.495021)\end{array}$ & 0.0008 \\
\hline ACI & $\begin{array}{l}-3.374349 * * \\
(-2.889753)\end{array}$ & 0.0141 & $\begin{array}{l}-3.504684 * \\
(-3.495021)\end{array}$ & 0.0097 \\
\hline OC & $\begin{array}{l}-3.535327 * \\
(-3.495021)\end{array}$ & 0.0089 & $\begin{array}{l}-3.550544 * \\
(-3.515047)\end{array}$ & 0.0085 \\
\hline IO & $\begin{array}{l}-5.983363^{*} \\
(-3.495021)\end{array}$ & 0.0000 & $\begin{array}{l}-5.961360^{*} \\
(-3.495021)\end{array}$ & 0.0000 \\
\hline FO & $\begin{array}{l}2.716004^{* * *} \\
(-2.581890) \\
\end{array}$ & 0.0747 & $\begin{array}{l}-2.951841 * * \\
(-2.889753)\end{array}$ & 0.0430 \\
\hline SIZE & $\begin{array}{l}-2.822654 * * * \\
(-2.581890) \\
\end{array}$ & 0.0586 & $\begin{array}{l}-2.965003^{*} \\
(-2.889753)\end{array}$ & 0.0416 \\
\hline DR & $\begin{array}{l}-3.937684^{*} \\
(-3.495021)\end{array}$ & 0.0026 & $\begin{array}{l}-3.957503^{*} \\
(-3.495021)\end{array}$ & 0.0024 \\
\hline
\end{tabular}

(*) $\mathrm{p}<0.01,(* *) \mathrm{p}<0.05,(* * *) \mathrm{p}<0.10$.

The results of the stationary test of Unit Root show that the BI (CR, LIQ, BS, OC, IO and DR) are stationary at level, since the significant level (Prob.) corresponding to variables are less than 0.01 . The variables (OPR, ACI, FO and SIZE) are stationary in different significant levels $(0.01,0.05$ and 0.10$)$, these results according to ADF test, with almost similar to PP test. Moreover, ADF test appears (DUAL) series with unit root, while this result rejected by PP test, which show that (DUAL) is stationary at (0.01) significant level. These results show that the null hypotheses of the unit root existence (non- Stationary) are rejected, which indicate that all mentioned variable are stationary at the level during the study period.

\subsubsection{Multicollinearity Test}

To test the existence of multicollinearity phenomena between model variables, Pearson correlation coefficients calculated between independent (predictor) variables, the results of testing multicollinearity between independents variables are explained by correlation matrices and VIF test as following:

Table 4: Correlation matrix for predictor variables

\begin{tabular}{|c|c|c|c|c|c|c|c|c|c|}
\hline & BS & $\mathrm{BI}$ & DUAL & ACI & $\mathrm{OC}$ & $\mathrm{IO}$ & FO & SIZE & DR \\
\hline $\mathrm{BS}$ & 1.000 & & & & & & & & \\
\hline BI & $\begin{array}{l}- \\
0.533 * *\end{array}$ & 1.000 & & & & & & & \\
\hline DUAL & -0.123 & -0.039 & 1.000 & & & & & & \\
\hline ACI & -0.164 & 0.126 & -0.156 & 1.000 & & & & & \\
\hline $\mathrm{OC}$ & $-\overline{0.406 * *}$ & -0.017 & 0.124 & -0.129 & 1.000 & & & & \\
\hline IO & 0.105 & 0.142 & $-\overline{0.304 * *}$ & 0.146 & - & 1.000 & & & \\
\hline $\mathrm{FO}$ & $\overline{0.259 * *}$ & -0.038 & $0.293 * *$ & -0.171 & $0.769 * *$ & $-0.429 * *$ & 1.000 & & \\
\hline SIZE & $0.347 * *$ & -0.121 & -0.136 & $0.359 * *$ & 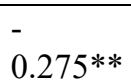 & -0.069 & -0.128 & 1.000 & \\
\hline DR & 0.081 & 0.017 & 0.068 & 0.062 & -0.001 & $0.254 * *$ & -0.085 & 0.116 & 1.000 \\
\hline
\end{tabular}

(**) Significant at $0.01,(*)$ Significant at 0.05

The above table shows that maximum value of correlation coefficient $(0.769)$ occurred between (OC and FO), this value may indicate there is no multicollinearity problem, otherwise the values were less than or equals $( \pm 0.769)$, which means there were no perfect relationship between variables. In the statistical literature the value $(0.80)$ and 
more considered as an indicator of multicollinearity existence(Gujarati \& Porter, 2004).

\subsection{Regression analysis and hypothesis Results}

This part of study deals with regression results of explained variables (credit, liquidity and operating risks) and the explanatory variables (BS, BI, DUAL, ACI, OC, IO, FO, SIZE and DR) of the study. The results of regression generated from fixed and random effect models. The results were as following:

\subsubsection{The First hypothesis}

\subsubsection{Regression analysis}

H1: There is no statistically significant impact for governance mechanisms (BS, BI, DUAL, ACI, OC, IO and FO) on the credit risks of the Jordanian banks.

Table 5: Regression results for $\mathrm{H} 1$

\begin{tabular}{|l|l|l|l|l|}
\hline Variable & Co-eff & Std Error & T-value & P-value* \\
\hline BS & 0.395 & 0.107 & 3.703 & 0.000 \\
\hline BI & -0.045 & 0.011 & -4.084 & 0.000 \\
\hline DUAL & 2.989 & 0.910 & 3.283 & 0.001 \\
\hline ACI & -0.035 & 0.016 & -2.237 & 0.028 \\
\hline OC & 0.017 & 0.016 & 1.042 & 0.300 \\
\hline IO & 0.034 & 0.013 & 2.596 & 0.011 \\
\hline FO & -0.010 & 0.013 & -0.772 & 0.442 \\
\hline SIZE & -0.532 & 0.409 & -1.301 & 0.197 \\
\hline DR & -0.529 & 0.095 & -5.591 & 0.000 \\
\hline Constant & 53.994 & 9.792 & 5.514 & 0.000 \\
\hline R-squared & & & \\
Adjusted R-squared & 0.388 & & \\
F-statistic & 0.329 & & \\
Prob*(F-statistic) & 6.609 & & \\
D-W & 0.000 & & \\
\hline
\end{tabular}

*Significant at 0.05 level.

\subsubsection{Hypothesis Results}

Hypothesis 1 :There is an effect with a clear statistic significant between the impact of Internal Corporate Governance Mechanisms and Credit Risk.

As illustrated in table has above table reports that R Square, the coefficient of determination equal to (0.388), which means that about (38.8\%) of the variation in credit risks is explained by the model. The significance value of the $\mathrm{F}$ statistic $(\mathrm{F}=6.609)$ is (Prob $\mathrm{F}=0.000)$ less than 0.05 , which means that the effect of independent variables aggregated is significant.

Moreover, the coefficients of the regression states that the $(\mathrm{BI})$ has a significant effect on credit risk, where coefficient value equals $(0.395)$ is significant with $(\mathrm{t}=3.703)$ and $(\mathrm{P}$-value $=0.000)$ less than 0.05 , $(\mathrm{BI}) \mathrm{has}$ a significant effect, where coefficient value equals $(-0.045)$ is significant with $(\mathrm{t}=-4.084)$ and $(\mathrm{P}$-value $=0.000)$. (DUAL) has significant effect, where coefficient value equals $(2.989)$ is significant with $(\mathrm{t}=3.283)$ and $(\mathrm{P}$-value $=0.001)$. Also, $(\mathrm{ACI})$ has significant effect, where coefficient value equals $(-0.035)$ is significant with $(\mathrm{t}=-2.237)$ and $(\mathrm{P}$-value $=0.028),(\mathrm{OC})$ has no significant effect, where coefficient value equals $(0.017)$ is not significant with $(\mathrm{t}=1.042)$ and $(\mathrm{P}$-value $=0.300)$. $(\mathrm{IO})$ has significant effect, where coefficient value equals $(0.034)$ is significant with $(\mathrm{t}=2.596)$ and $(\mathrm{P}$-value $=0.011)$. Also, $(\mathrm{FO})$ has no significant effect, where coefficient value equals $(-0.010)$ is not significant with $(\mathrm{t}=-0.772)$ and $(\mathrm{P}$-value $=0.442)$. Finally, $(\mathrm{SIZE})$ has not significant effect, where coefficient value equals $(-0.532)$ is not significant with $(\mathrm{t}=-1.301)$ and $(\mathrm{P}-\mathrm{value}=0.197)$, and $(\mathrm{DR})$ has significant effect, where coefficient value equals $(-0.529)$ is significant with $(\mathrm{t}=-5.591)$ and $(\mathrm{P}$-value $=0.000)$

Moreover, $(\mathrm{D}-\mathrm{W}=1.796)$ indicates there is no serial correlation, where Durbin-Watson value nearby (2) indicate there is no serial correlation between error terms.

\subsubsection{The Second hypothesis}

\subsubsection{Regression analysis}

H2: There is no statistically significant impact for governance mechanisms (BS, BI, DUAL, ACI, OC, IO and FO) on the liquidity risks of the Jordanian banks. 
Table 6: Regression results for $\mathrm{H} 2$

\begin{tabular}{|l|l|l|l|l|}
\hline Variable & Co-eff & Std Error & T-value & P-value* \\
\hline BS & 0.327 & 0.223 & 1.463 & 0.147 \\
\hline BI & -0.033 & 0.010 & -3.223 & 0.002 \\
\hline DUAL & -0.763 & 0.445 & -1.715 & 0.090 \\
\hline ACI & -0.052 & 0.028 & -1.903 & 0.060 \\
\hline OC & 0.003 & 0.028 & 0.110 & 0.913 \\
\hline IO & 0.138 & 0.019 & 7.439 & 0.000 \\
\hline FO & 0.054 & 0.014 & 3.818 & 0.000 \\
\hline SIZE & 2.881 & 0.352 & 8.173 & 0.000 \\
\hline DR & -0.028 & 0.099 & -0.288 & 0.774 \\
\hline Constant & -51.868 & 12.429 & -4.173 & 0.000 \\
\hline R-squared & & & \\
Adjusted R-squared & 0.456 & & \\
F-statistic & 0.404 & & \\
Prob*(F-statistic) & 8.767 & & \\
D-W & 0.000 & & \\
\hline
\end{tabular}

\subsubsection{Hypothesis Results}

*Significant at 0.05 level.

Hypothesis 2 :There is an effect with a clear statistic significant between the impact of Internal Corporate Governance Mechanisms and liquidity risk.

The above table reports that R Square, the coefficient of determination equal to (0.456), which means that about $(45.6 \%)$ of the variation in liquidity risks is explained by the model. The significance value of the $\mathrm{F}$ statistic $(F=8.767)$ is (Prob $F=0.000)$ less than 0.05 , which means that the effect of independent variables aggregated is significant.

Moreover, the coefficients of the regression states that the (BI) has no significant effect on liquidity risks, where coefficient value equals $(0.327)$ is not significant with $(\mathrm{t}=1.463)$ and $(\mathrm{P}$-value $=0.147)$ greater than 0.05 , (BI) has a significant effect, where coefficient value equals $(-0.033)$ is significant with $(\mathrm{t}=-3.223)$ and $(\mathrm{P}$-value $=0.002)$. (DUAL) has no significant effect, where coefficient value equals $(-0.763)$ is not significant with $(t=$ $1.715)$ and $(\mathrm{P}-\mathrm{value}=0.090)$. Also, $(\mathrm{ACI})$ has no significant effect, where coefficient value equals $(-0.052)$ is not significant with $(\mathrm{t}=-1.903)$ and $(\mathrm{P}$-value $=0.060),(\mathrm{OC})$ has no significant effect, where coefficient value equals $(0.003)$ is not significant with $(\mathrm{t}=0.110)$ and $(\mathrm{P}$-value $=0.913)$. (IO) has significant effect, where coefficient value equals $(0.138)$ is significant with $(\mathrm{t}=7.439)$ and $(\mathrm{P}$-value $=0.000)$. Also, $(\mathrm{FO})$ has a significant effect, where coefficient value equals $(0.054)$ is not significant with $(\mathrm{t}=3.818)$ and $(\mathrm{P}$-value $=0.000)$. Finally, (SIZE) has a significant effect, where coefficient value equals $(2.881)$ is significant with $(\mathrm{t}=8.173)$ and $(\mathrm{P}$-value $=0.000)$, and (DR) has no significant effect, where coefficient value equals $(-0.028)$ is not significant with $(\mathrm{t}=-0.288)$ and $(\mathrm{P}-$ value $=0.774$ )

Moreover, $(\mathrm{D}-\mathrm{W}=1.927)$ indicates there is no serial correlation, where Durbin-Watson value nearby (2) indicate there is no serial correlation between error terms.

\subsubsection{The Their hypothesis}

3.3.3.1. Regression analysis

H3: There is no statistically significant impact for governance mechanisms (BS, BI, DUAL, ACI, OC, IO and FO) on the operating risks of the Jordanian banks. 
Table 7: Regression results for $\mathrm{H} 3$

\begin{tabular}{|l|l|l|l|l|}
\hline Variable & Co-eff & Std Error & T-value & P-value* \\
\hline BS & -0.009 & 0.007 & -1.384 & 0.170 \\
\hline BI & -0.002 & 0.001 & -2.132 & 0.036 \\
\hline DUAL & -0.255 & 0.043 & -5.973 & 0.000 \\
\hline ACI & -0.001 & 0.001 & -1.453 & 0.150 \\
\hline OC & -0.002 & 0.001 & -2.285 & 0.025 \\
\hline IO & 0.002 & 0.001 & 3.175 & 0.002 \\
\hline FO & 0.001 & 0.001 & 2.652 & 0.009 \\
\hline SIZE & 0.989 & 0.012 & 85.309 & 0.000 \\
\hline DR & -0.009 & 0.004 & -2.184 & 0.032 \\
\hline Constant & -2.433 & 0.224 & -10.852 & 0.000 \\
\hline R-squared & & & \\
Adjusted R-squared & 0.972 & & \\
F-statistic & 0.969 & & \\
Prob*(F-statistic) & 365.257 & & \\
D-W & 0.000 & & \\
\hline
\end{tabular}

*Significant at 0.05 level.

\subsubsection{Hypothesis Results}

Hypothesis 3: There is an effect with a clear statistic significant between the impact of Internal Corporate Governance Mechanisms and operational risk.

The above table reports that R Square, the coefficient of determination equal to (0.972), which means that about $(97.2 \%)$ of the variation in operating risks is explained by the model. The significance value of the $\mathrm{F}$ statistic $(\mathrm{F}=365.257)$ is (Prob $\mathrm{F}=0.000)$ less than 0.05 , which means that the effect of independent variables aggregated is significant.

Moreover, the coefficients of the regression states that the (BI) has no significant effect on operating risks, where coefficient value equals $(-0.009)$ is not significant with $(\mathrm{t}=-1.384)$ and $(\mathrm{P}$-value $=0.170)$ greater than 0.05 , (BI) has a significant effect, where coefficient value equals $(-0.002)$ is significant with $(\mathrm{t}=-2.132)$ and $(\mathrm{P}$-value $=0.036)$. (DUAL) has a significant effect, where coefficient value equals $(-0.255)$ is significant with $(\mathrm{t}=-5.973)$ and (P-value $=0.000)$. Also, $(\mathrm{ACI})$ has no significant effect, where coefficient value equals $(-0.001)$ is not significant with $(\mathrm{t}=-1.453)$ and $(\mathrm{P}$-value $=0.150),(\mathrm{OC})$ has a significant effect, where coefficient value equals $(-$ $0.002)$ is significant with $(\mathrm{t}=-2.285)$ and $(\mathrm{P}$-value $=0.025)$. (IO) has a significant effect, where coefficient value equals $(0.002)$ is significant with $(\mathrm{t}=3.175)$ and $(\mathrm{P}$-value $=0.002)$. Also, $(\mathrm{FO})$ has a significant effect, where coefficient value equals $(0.001)$ is significant with $(\mathrm{t}=2.652)$ and $(\mathrm{P}$-value $=0.009)$. Finally, (SIZE) has a significant effect, where coefficient value equals $(0.989)$ is significant with $(\mathrm{t}=85.309)$ and $(\mathrm{P}$-value $=0.000)$, and (DR) has a significant effect, where coefficient value equals $(-0.009)$ is significant with $(\mathrm{t}=-2.184)$ and $(\mathrm{P}-\mathrm{value}$ $=0.032$ )

Moreover, $(\mathrm{D}-\mathrm{W}=1.715)$ indicates there is no serial correlation, where Durbin-Watson value nearby (2) indicate there is no serial correlation between error terms.

Table 8: Summary of the research result

$\begin{array}{llll}\text { Hypothesis } & \begin{array}{l}\text { Hypothesis statement } \\ \text { H1 }\end{array} & \begin{array}{l}\text { There is an effect with a clear statistic significant between the impact of } \\ \text { Internal Corporate Governance Mechanisms and Credit Risk. }\end{array} & 0.000 \\ \text { H2 } & \begin{array}{l}\text { There is an effect with a clear statistic significant between the impact of } \\ \text { Internal Corporate Governance Mechanisms and liquidity risk. }\end{array} & 0.000 & \text { Accept } \\ \text { H3 } & \begin{array}{l}\text { There is an effect with a clear statistic significant between the impact of } \\ \text { Internal Corporate Governance Mechanisms and operational risk. }\end{array} & 0.000 & \text { Accept }\end{array}$

*Represent the significance at the $5 \%$ level

\section{CONCLUSIONS}

This study was conducted using data collected from annual reports of 13 Jordanian banks listed on Bursa Amman for the period of 2009 to 2016. This research focused on all Jordanian commercial banks. The statistical method used for this study was Panel data analysis. Three hypotheses were developed by the researchers based on past studies (refers to table 4).

The results show that the first hypothesis which suggests that the Internal corporate governance mechanisms had an effect on credit risk with R Square, the coefficient of determination equal to (0.388), which means that about $(38.8 \%)$ of the variation in credit risks, which means that the effect of independent variables aggregated is significant. This result is consistent with those found in prior research (Al-Smadi, 2013; Huang \& Wang, 2015; 
Hutchinson, Seamer, \& Chapple, 2015) While different with (Al-Zamel, 2015; Eling \& Marek, 2014). The hypothesis 2 also reveals that the presence of the effect of independent variables aggregated is significant. Where, R Square, the coefficient of determination equal to (0.456), which means that about $(45.6 \%)$ of the variation in liquidity risks. This result is consistent with those found in prior research (Alam \& Ali Shah, 2013; Eling \& Marek, 2014)While different with (Adams \& Mehran, 2003; Laeven \& Levine, 2009). The hypothesis 3 also reveals that the presence of the effect of independent variables aggregated is significant. Where, R Square, the coefficient of determination equal to (0.972), which means that abou $(97.2 \%)$ of the variation in operating risks. This result is consistent with those found in prior research (Pathan, 2009)While different with (HAMDAN 2105).

\section{Reference}

(BIS), B. o. I. S. (2014).

Adams, R. B., \& Mehran, H. (2003). Is corporate governance different for bank holding companies? Available at SSRN 387561.

Aksoy, A., \& Dayi, F. (2017). BİRDEN FAZLA BORSADA İŞLEM GÖREN HİSSE SENETLERININ DEĞERLEMESI: TEORIK BİR İNCELEME. Kastamonu University Journal of Economics \& Administrative Sciences Faculty(15).

Al-Smadi, M. O. (2013). Examining the relationship between corporate governance and banks' performance, and risk in Saudi Arabia. European journal of economics, finance and administrative sciences, 16(2), 59-62.

Al-Zamel, N. (2015). The Impact of Internal Corporate Governance Instruments on Bank's Risk of Jordanian Islamic Banks (period 2008-2013). The World Islamic Science University \& Education University (wise), Amman.

Alam, A., \& Ali Shah, S. Z. (2013). Corporate governance and its impact on firm risk. International Journal of Management, Economics and Social Sciences, 2(2), 76-98.

Alhumoudi, H. Y. (2016). Corporate Governance Mechanisms and Firms' Performance: An Empirical Analysis of Firms Listed on the Saudi Stock Exchange. International Journal of Accounting and Financial Reporting, 6(2), 101-145.

Christensen, J., Kent, P., \& Stewart, J. (2010). Corporate governance and company performance in Australia. Australian Accounting Review, 20(4), 372-386.

Civan, M., \& Dayı, F. (2014). 'Altman Z Skoru ve Yapay Sinir Ağı Modeli İle Sağlık İşletmelerinde Finansal Başarısızlık Tahmini. Akademik Bakış Dergisi, 41.

Dickey, D. A., \& Fuller, W. A. (1979). Distribution of the estimators for autoregressive time series with a unit root. Journal of the American statistical association, 74(366a), 427-431.

Eling, M., \& Marek, S. D. (2014). Corporate governance and risk taking: Evidence from the UK and German insurance markets. Journal of Risk and Insurance, 81(3), 653-682.

Fama, E. F., \& Jensen, M. C. (1983). Separation of ownership and control. The journal of law and Economics, 26(2), 301-325.

Fogelberg, L., \& Griffith, J. M. (2000). Control and bank performance. Journal of Financial and Strategic Decisions, 13(3), 63-69.

Gujarati, D., \& Porter, D. C. (2004). Basic Econometrics, 2004. Editura McGraw-Hill, 858.

Huang, Y. S., \& Wang, C.-J. (2015). Corporate governance and risk-taking of Chinese firms: The role of board size. International Review of Economics \& Finance, 37, 96-113.

Hutchinson, M., Seamer, M., \& Chapple, L. E. (2015). Institutional investors, risk/performance and corporate governance. The International Journal of Accounting, 50(1), 31-52.

Jensen, M. C. (1993). The modern industrial revolution, exit, and the failure of internal control systems. The journal of finance, 48(3), 831-880.

JFED, J. F. f. E. D. (2003). The State of Corporate Governance in Jordan,. The Economic Policy Dialogue,, 1, 16.

Laeven, L., \& Levine, R. (2009). Bank governance, regulation and risk taking. Journal of financial economics, 93(2), 259-275.

Lensink, R., \& Morrissey, O. (2006). Foreign direct investment: Flows, volatility, and the impact on growth. Review of International Economics, 14(3), 478-493.

Liao, L. K. C., Mukherjee, T., \& Wang, W. (2015). Corporate governance and capital structure dynamics: An empirical study. Journal of Financial Research, 38(2), 169-192.

Ly, K. C. (2015). Liquidity Risk, Regulation and Bank Performance: Evidence from European Banks. Global Economy and Finance Journal, 8(1), 11-33.

Marn, J. T. K., \& Romuald, D. F. (2012). The impact of corporate governance mechanism and corporate performance: A study of listed companies in Malaysia. Journal for the advancement of science \& arts, 3(1), $31-45$.

McNulty, T., Florackis, C., \& Ormrod, P. (2012). Corporate Governance and Risk: A Study of Board Structure 
and Process. ACCA Research Report, 129.

Obradovich, J., \& Gill, A. (2013). The impact of corporate governance and financial leverage on the value of American firms.

Pathan, S. (2009). Strong boards, CEO power and bank risk-taking. Journal of Banking \& Finance, 33(7), 13401350 .

Phillips, P. C., \& Perron, P. (1988). Testing for a unit root in time series regression. Biometrika, 75(2), 335-346.

Pi, L., \& Timme, S. G. (1993). Corporate control and bank efficiency. Journal of Banking \& Finance, 17(2-3), $515-530$

Salhi, B., \& Boujelbene, Y. (2012). Effect of internal banking mechanisms of governance on the risk taking by the Tunisian banks. International Journal of Economics, Finance and Management, 1(1).

Sants, H. (2008). The FSA's Supervisory Enhancement Programme, in response to the Internal Audit Report on supervision of Northern Rock.

Shrieves, R. E., \& Dahl, D. (1992). The relationship between risk and capital in commercial banks. Journal of Banking \& Finance, 16(2), 439-457.

Spuchl'áková, E., Valašková, K., \& Adamko, P. (2015). The credit risk and its measurement, hedging and monitoring. Procedia Economics and Finance, 24, 675-681.

SUPERVISION, B. C. O. B. (2010). Basel III: A global regulatory framework for more resilient banks and banking systems. Basel, Bank for International Settlements.

Tahir, S., Rehman, R., \& Rehman.Naveed. (2015). Corporate governance and financial leverage impact on the value of firms

(Evidence from Textile Sector Pakistani Listed Companies). Research Journal of Economics\&Business studies, 3(2251-1555), 25-33.

Trinh, T. H., Duyen, T. T., \& Thao, N. T. (2015). The Impact of Corporate Governance on Financial Risk in Vietnamese Commercial Banks. International Journal of Economics and Finance, 7(7), 123.

Tsorhe, J. S., Aboagye, A. Q., \& Kyereboah-Coleman, A. (2011). Corporate governance and bank risk management in Ghana. University of Ghana Business School.

Ulusoy, T. (2008a). Analysis of Government Bonds' Compound Interest Rates between 1996-2006 in the ISE Bonds and Bills Secondary Market Using Grey System Theory. The Journal of American Academy of Business, Cambridge, 14 Num.2, The Library of Congress, Washington, DC,

Ulusoy, T. (2008b). Systematic Risk and Firm Financial Structure: Evidence on Istanbul Stock Exchange. The Business Review, Cambridge, 11(2), 226-231.

Ulusoy, T. (2011). Financial power analysis of countries: Transmitters (adsorbents), setters and unresistants. African Journal of Business Management, 5(22), 9087-9105.

Woods, M., \& Dowd, K. (2008). Financial risk management for management accountants. Management Accounting Guideline, London: CIMA.

Yaseen, H., \& Al-Amarneh, A. (2015). Corporate Governance and the Financial Leverage: Evidence from Jordan. 6.

Zhong, K., Gribbin, D. W., \& Zheng, X. (2007). The effect of monitoring by outside blockholders on earnings management. Quarterly Journal of Business and Economics, 37-60. 